\title{
IMPLEMENTASI NILAI-NILAI PANCASILA DALAM WAWASAN KEBANGSAAN DI ERA GLOBALISASI
}

\author{
Lisnawati Suargana ${ }^{1}$, Dinie Anggraeni Dewi ${ }^{2}$ \\ Pendidikan Guru Sekolah Dasar-Universitas Pendidikan Indonesia Cibiru \\ Jl. Pendidikan No.15, Cibiru Wetan, Cileunyi, Bandung, Jawa Barat 40625 \\ Email : lisnawati.suargana.04@ upi.edu ${ }^{1}$; $\underline{\text { dinianggreanidewi@edu.id }}^{2}$
}

\begin{abstract}
ABSTRAK
Bangsa Indonesia selaku negara yang tidak dapat menjauhi tantangan globalisasi, namun dengan berpegang pada Pancasila selaku panduannya, prinsip Indonesia hendaknya bisa mempertahankan jati diri serta eksistensinya. Riset ini berisi tentang apabila memelihara semangat nasionalisme dalam benak generasi muda semenjak masa anak- anak akan membuat mereka lebih tangguh terhadap pengaruh negatif serta pergantian moral yang menjadi- jadi di masa globalisasi. Jadi, dengan memantapkan moralitas serta etika lewat pembelajaran Pancasila, generasi muda Indonesia bakal lebih siap buat hadapi globalisasi serta mempertahankan fakta diri Indonesia dikala yang bersamaan. Nilai kebudayaan yang jadi ciri bangsa Indonesia, semacam gotong royong, silahturahmi, ramah tamah dalam warga jadi keistimewaan dasar yang bisa menjadikan masingmasing orang warga Indonesia untuk mencintai serta melestarikan kebudayaan bangsa sendiri. Tetapi ciri masyarakat Indonesia yang diketahui selaku masyarakat yang ramah serta sopan santun disaat ini mulai pudar semenjak masuknya budaya asing ke Indonesia yang tidak bisa dipilih dengan baik oleh warga Indonesia. Hingga, dalam Mengenai ini pemerintah mempunyai peranan berarti buat mempertahankan nilai- nilai kebudayaan Indonesia dalam kehidupan masyarakatnya.
\end{abstract}

Kata Kunci : Pancasila, kebangsaan, Globalisasi

\begin{abstract}
Indonesia as a country that cannot resist the challenges of globalization, but by adhering to the pancasila as its guidelines, its principles should be able to defend itself and existence. The research is about keeping a nationalistic spirit in the minds of youth since childhood will make them more resilient to the negative influences and the demoralizations of globalization. So, by reinforcing morality and ethics through pancasila study, the Indonesian younger generation will be better equipped to face globalization and maintain Indonesian fact at the same time. The cultural value of the Indonesian people, such as cooperation, silahturahmi, is a basic privilege that can make indonesians love and preserve their own culture. But the Indonesian people known as a friendly and civilised society have begun to wane since the influx of foreign cultures into Indonesia that Indonesia has not been able to choose well. Until then, governments have a meaningful role to maintain Indonesian cultural values in their societies
\end{abstract}

Keywords: Pancasila, Nationality, Globalization 


\section{PENDAHULUAN}

Salah satu kasus yang dialami bangsa Indonesia disaat ini ialah memudarnya semangat nasionalisme serta patriotisme di golongan generasi muda. Mengenai ini diakibatkan banyaknya pengaruh budaya asing yang banyak masuk di negeri kita, akibatnya banyak generasi muda yang melupakan budaya sendiri sebab menyangka bila budaya asing ialah budaya yang lebih modern dibandingkan budaya bangsa sendiri. Mengenai ini berdampak nilai- nilai luhur bangsa banyak diabaikan hampir berlangsung disebagian besar generasi muda. ( Irhandayaningsih, 2012)

Pancasila memegang peranan berarti dalam menyikapi perkembangan jaman, karena nilai- nilai dasar Pancasila dapat dibesarkan melalui kehidupan warga Indonesia (Sanusi 2019). Pancasila yakni pemikiran hidup bangsa yang pada dasarnya dapat membawakan arahan normatif, komentar dan pedoman dalam segala bidang kehidupan bangsa. Artinya nilai- nilai Pancasila harus diterapkan di segala bidang, sangat utama di bidang pendidikan (Sulianti, Effendi dan Sadiah 2020). Dalam proses pendidikan perlu diterapkan nilai- nilai Pancasila biar norma dan nilai moral yang tercantum dalam Pancasila dapat disatukan ke dalam diri partisipan didik dan dapat tingkatkan pembangunan bangsa Indonesia. Peran pendidikan dalam pengembangan sumber tenaga manusia sangat vital buat kelangsungan hidup pemerintah (Djafri 2020).

Pancasila mempunyai sederet nilai ialah ketuhanan, kemanusiaan, persatuan, demokrasi serta keadilan. Kelima nilai ini ialah satu kesatuan yang utuh dengan satu tujuan. Nilai- nilai dasar Pancasila semacam ketuhanan, kemanusiaan, persatuan, demokrasi serta keadilan bertabiat umum serta obyektif, maksudnya nilai- nilai tersebut bisa digunakan serta diakui oleh negeri lain. Selaku pandangan hidup bangsa serta negeri Indonesia, Pancasra pada hakikatnya tidak cuma seorang ataupun sekelompok orang selaku hasil pemikiran ataupun pemikiran pandangan hidup lain di dunia, namun Pancasra pula menonjol dari nilai adat serta budaya di Indonesia Nilai- nilai agama serta nilai- nilai agama yang tercantum dalam kehidupan warga.

Globalisasi sudah membawa pergantian tatanan dunia internasional, serta berakibat langsung pada pergantian di negara- negara di dunia. Keahlian mengalami tantangan yang sangat mendasar, apalagi secara spiritual serta kebangsaan, hendak menghantam kehidupan berbangsa, sosial serta politik. Benteng terakhir merupakan kepercayaan nasional yang berlandaskan negeri Pancasila, serta negeri Pancasila Ialah benteng buat mengalami tantangan di masa yang terus menjadi mengglobal. Pada kesempatan- kesempatan yang cocok semacam Peringatan Hari Sumpah Pemuda, Hari Kemerdekaan, Hari Pahlawan serta hari libur nasional yang lain, nilai- nilai Pancasila bisa diaplikasikan kepada siswa di masa globalisasi. Mahasiswa berupaya buat mencapai hasil yang brilian serta belajar dengan aktif. Dia betul- betul sudah memainkan bakatnya dengan sanggup membangun reputasi yang baik untuk negeri serta negaranya, serta dia bangga serta bangga bisa memakai produk dalam negara tanpa pamrih buat memajukan perekonomian negeri.

Pancasila kerap ditatap selaku pandangan hidup yang mendapati" ideologi global" semacam kapitalisme serta liberalisme. Pancasila dibentuk buat kesejahteraan bersama serta keadilan sosial untuk segala rakyat Indonesia. Di sisi lain, kita hidup dalam globalisasi yang penuh dengan hukum serta ketentuan kapitalis, pasar leluasa serta terbuka. Kita wajib percaya serta teguh jika kita wajib mendedikasikan seluruh ini buat kesejahteraan bersama buat menggapai keadilan sosial. Negeri yang pintar di masa globalisasi tidaklah negeri yang terus menerus meringik, pasrah serta marah, melainkan negeri yang dapat jadi sumber kesejahteraan di panggung global. Kami memakai teknologi, modal ataupun data dengan benar buat tingkatkan kesejahteraan serta kepentingan kami. Tidak mau jadi pecundang. Marilah kita menjadi pemenang globalisasi. 


\section{TINJUAN PUSTAKA}

Era globalisasi pula telah mengganti tatanan dunia yang meliputi tatanan kehidupan dunia dimanapun di dunia, orang bisa dengan cepat berinteraksi serta melihat tatanan dunia dimanapun mereka terletak. Dari sudut pandang politik, globalisasi sudah bawa akibat ataupun pengaruh yang positif, semacam penyelenggaraan pemerintahan yang terbuka serta demokratis. Dari aspek ekonomi misalnya, terbukanya pasar internasional, kenaikan peluang kerja serta kenaikan devisa negeri. Dari perspektif sosial serta budaya, kita dapat meniru pola pikir yang baik dari negeri maju yang lain, semacam etika serta disiplin profesi yang lebih besar, dan iptek.

Pembelajaran nasional ataupun pembelajaran kewarganegaraan serta pembelajaran pancasila merupakan pembelajaran yang ditanamkan semenjak pendidikan dasar. Tujuan pembelajaran ini supaya peserta didik sanggup serta ingin mengaplikasikan nilai- nilai Pancasila semenjak dini. Dengan demikian mahasiswa sebagai pribadi yang menjadikan negara Indonesia lebih bermartabat serta tumbuh ke arah yang lebih baik.

Tetapi, dilihat dari suasana dikala ini.

Pembelajaran Pancasila serta kewarganegaraan tampaknya memenuhi banyak pembelajaran lain yang diajarkan dalam pendidikan. Ini hanya karna nilai yang wajib diterapkan sesungguhnya wajib diabaikan. Tampaknya, cuma sedikit siswa yang membuang nilai- nilai tersebut serta mengubahnya dengan nilai- nilai global yang tidak sejalan dengan Pancasila.

Globalisasi sendiri merupakan permasalahan nasional. Globalisasi mempunyai aspek positif serta negatif. Tetapi dibanding dengan aspek positifnya, penyerapan hal- hal negatif malah lebih banyak diserap oleh kanak- kanak Tanah Air. Perihal ini berakibat pada pergantian nilainilai kebangsaan yang sudah di jaga oleh nenek moyang serta pendiri semenjak lama.

Semacam yang diketahui, Globalisasi membolehkan tiap orang meningkatkan budaya. Pertukaran budaya semacam ini bisa menarik orang, serta pada sesi lanjut, orang bisa memakai budaya ini apalagi dalam kehidupan tiap hari.

Nilai- nilai Pancasila sendiri ialah nilai- nilai yang mengaitkan karakter serta kebiasaan masyarakat lokal Indonesia. Tiap nilai Pancasila mewakili bangsa itu sendiri secara totalitas. Sebaliknya pada masa saat ini ini budaya selaku objek budaya merupakan budaya Barat. Pada dasarnya sebagian budaya barat mempunyai nilai yang lumayan baik serta tidak berlawanan dengan nilai pancasila. Tetapi mengacu pada ulasan di atas, sebagian besar anak muda di negara ini cenderung meniru budaya yang berkesan negatif, sehingga mendesak mereka sebagai orang yang tidak mengedepankan jati diri bangsa

Pada kesimpulannya kehidupan warga di masa globalisasi ini mewajibkan mereka nuntuk melestarikan nilai- nilai Pancasila. Perihal tersebut dilakukan untuk melindungi serta mengendalikan eksistensi nilai- nilai Pancasila. Di sisi lain, melestarikan nilainilai Pancasila pula sangat berguna untuk melindungi implementasi serta pelaksanaan nilai- nilai Pancasila oleh penerus Bangsa.

\section{Pancasila Selaku Suatu Peninggalan} Pendiri Bangsa

Asmaroini (2017) sempat menyatakan dalam makalahnya kalau Pancasila mengalami banyak tantangan dalam pembentukannya. Dia pula mengatakan kalau dalam proses ini, Pancasila mengalami ketegangan, konflik serta ketentuan pembuatan panitia. Para pendiri negeri dikala itu dihadapkan pada realitas kalau pada dikala itu sebagian besar warga Indonesia hidup dalam ketidakadilan yang diakibatkan oleh praktek- praktek penjajahan.

Masa penjajahan menjadikan warga Indonesia selaku orang dengan nasib yang sama. Kemiskinan serta kebodohan dikala itu telah jadi perihal yang lumrah. Masyarakat adat menyadari kalau pengalaman yang mereka temukan dikala itu dirasakan oleh banyak kerabat mereka di wilayah lain di Indonesia. Dalam perihal ini, warga hendak mempunyai atensi serta kemauan untuk melancarkan kampanye melawan ketidakadilan tersebut. 
Tidak hanya itu tokoh- tokoh perjuangan semacam Ir. Soekarno, Hatta, Moh. Yamien serta yang lain yakin kalau Indonesia wajib jadi negeri yang sejahtera serta bermartabat. Bangsa Indonesia merupakan bangsa yang hebat. Tidak hanya itu, negeri Indonesia pula tumbuh jadi banyak perbandingan yang relatif lingkungan. Dengan keadaan tersebut, Indonesia sudah jadi negeri yang bermacam- macam semenjak nenek moyangnya. Perbandingan jadi perlengkapan persatuan serta menciptakan banyak nilai, yang setelah itu diimplementasikan serta dijadikan bukti diri negeri.

Statment Pancasila timbul atas dasar tekad para pemimpin buat membangun negeri yang sejahtera, adil, serta berwawasan negara. Semacam yang sudah disinggung di atas, Indonesia mempunyai banyak keunikan selaku negara yang bersatu. Setelah itu memasukkan nilai yang diartikan dalam tiap sila yang saat ini diucap Pancasila. Tokohtokoh ini berharap dengan terdapatnya Pancasila, bangsa Indonesia jadi negeri yang dapat mengamalkan seluruh nilai yang di milikinya.

Para pemimpin berharap tumbuh jadi warga yang bermartabat, bertakwa, berakhlak mulia, adil serta bersatu lewat Pancasila, sehingga terbentuklah negeri yang bersatu.

Ringkasnya, secara totalitas Pancasila didirikan dengan harapan membangun negeri yang besar. Sedangkan itu, bagi Hariyono( 2014), ekspresi Pancasila tidak lebih dari sebab karakter- karakter tersebut menginginkan ekspresi dasar suatu negeri yang bisa mewakili seluruh kebutuhan rakyatnya, serta jadi pandangan hidup nasional yang bisa dianut oleh segala warga Indonesia.

\section{Pancasila Selaku Suatu Pandangan hidup Bangsa}

Secara universal pandangan hidup bisa berfungsi dalam melindungi keutuhan bangsa (Ubaidillah: 2000). Dalam pertumbuhan era saat ini ini, pandangan hidup membuat pemegangnya senantiasa menjajaki landasan pemikiran, ataupun menjajaki pandangan hidup. Di negara ini, pandangan hidup memegang peranan berarti dalam membentuk kepribadian bangsa. Pandangan hidup membuat warga mempunyai pemikiran yang sama tentang seluruh perihal.

Asmaroini (2017) menarangkan kalau pandangan hidup bahasa dimaksud selaku dasar pemikiran, cita- cita serta anggapan yang senantiasa dipegang teguh oleh pemiliknya. Sedangkan itu Kaelan (2005) menarangkan dalam bukunya kalau pandangan hidup( dalam perihal ini diucap pula Pancasila) mempunyai sebagian karakteristik yang khas. Kepribadian yang diartikan merupakan; 1) timbul dalam kondisi darurat; 2) merupakan kemauan buat mempunyai kemauan yang luas serta terprogram; 3) memasukkan banyak tingkatan pemikiran; 4) jadi pemikiran dengan pola yang sangat sistematis; 5) terkesan eksklusif, Absolut serta umum, 6) mempunyai karakteristik empiris serta normatif, 7) jadi suatu yang gampang dimanipulasi serta dikomunikasikan, 8) pandangan hidup umumnya bersumber dari gerakan politik.

Selaku pandangan hidup negeri, Pancasila tidak bersumber dari bermacam pandangan hidup eksternal, melainkan murni dari adat istiadat, agama, serta nilai- nilai bangsa Indonesia. Dengan kata lain, penulis bisa menampilkan kalau secara universal Pancasila bersumber dari bangsa Indonesia serta pula mewakili bangsa Indonesia itu sendiri. Sedangkan itu, buat mempertegas perihal tersebut, Kaelan serta Ahmad Zubaidi( 2007) mengemukakan kalau modul pembuat Pancasila sepanjang ini merupakan pemikiran warga Indonesia terhadap warga, adat istiadat, budaya serta nilai- nilai agama.

Selaku pandangan hidup bangsa, Pancasila ialah landasan serta/ ataupun landasan tiap lembaga hukum, politik, serta kemasyarakatan di Indonesia (Suparlan: 2012). Selaku pandangan hidup, Pancasila pula menampung tiap kelompok yang mewakili bangsa dalam wadah yang diucap "Bineka Tunggal Ika" ataupun dimaksud selaku wadah dengan pemikiran yang berbeda namun sama. 
Kedudukan Pancasila dalam pandangan hidup bangsa sudah diperjelas dalam Pembukaan UUD 1945 (Asmaroini: 2017). Asmarone melanjutkan, selaku teologi bangsa, Pancasila wajib terus diterapkan dalam tiap kehidupan berbangsa serta bernegara. Konon inilah implementasi penuh Pancasila dalam kehidupan berbangsa.

Di sisi lain, untuk pandangan hidup sesuatu negara, Pancasila wajib sanggup jadi tameng spesial untuk generasi muda. Dengan terdapatnya Pancasila, bila diimplementasikan dengan baik hingga generasi muda wajib sanggup membedakan yang baik dari yang kurang baik dari globalisasi. Pancasila sendiri memiliki sebagian nilai luhur yang wajib diterapkan pada tiap penduduk Negara Kesatuan Republik Indonesia.

\section{METODOLOGI PENELITIAN}

Penelitian ini memakai tata cara penelitian literatur ialah dengan serangkaian aktivitas yang berkenaan dengan tata cara pengumpulan informasi pustaka, membaca serta mencatat, dan mengelolah bahan yang berkaitan dengan penelitian ini

Instrument dalam penelitian ini ialah peneliti sendiri dimana data- data yang diperoleh mempunyai mutu dan maknamakna tertentu yang didapatkan lewat penelusuran pustaka. Analisis penelitian ini memakai pendekatan kualitatif sebab informasi yang dipaparkan berbentuk deskripsi yang dijabarkan dalam wujud statment.

Data yang dipaparkan didapat dari membaca teori- teori, menganalisis, serta menguasai yang setelah itu disimpulkan dari apa yang sudah didapat dengan sumbersumber yang relevan serta berkaitan.

\section{HASIL PENELITIAN DAN PEMBAHASAN}

Globalisasi menantang kekuatan pelaksanaan faktor jati diri bangsa Indonesia lewat agen budaya luar paling utama media massa. Warga lebih tertarik dengan budaya baru yang ditawarkan agen budaya luar terutama media televise, hp, ataupun internet dibanding dengan budaya kita sendiri. Terdapatnya pertentangan antara nilai- nilai yang bersumber dari budaya bangsa Indonesia dengan nilai- nilai yang dibawa oleh agen globalisasi tersebut menyebabkan terbentuknya konflik nilai pada diri seorang.

Ada pula sebagian analisis informasi diperoleh dari hasil penelitian merupakan sebagai berikut:

\section{Nilai Pancasila yang Mewakili Warga Indonesia}

Selaku pandangan hidup sesuatu negara, Pancasila telah mempunyai sebagian nilai luhur yang mewakili tiap bangsa Indonesia. Nilai- nilai tersebut pada dasarnya mencakup seluruh aspek, kelompok serta adat istiadat tiap warga serta wilayah di Indonesia. Senada dengan perihal tersebut, Suko Wiyono (2013) pula menguraikan nilai serta ciri kedudukan Pancasila dalam pandangan hidup negara dalam buku tersebut. Baginya, terdapat sebagian nilai yang betul- betul mewakili warga Indonesia. Nilai- nilai tersebut meliputi:

a. Ketuhanan yang Maha Esa

Pada sila awal warga Indonesia memahami "Ketuhanan yang Maha Esa." Sila tersebut memiliki sebagian nilai yang berkaitan dengannya: 1) Esensi seorang yang beriman serta menaati Tuhan Yang Maha Esa; 2) Tiap orang mempunyai kebebasan berkeyakinan serta berkeyakinan, yang mana merupakan Kebebasan dasar serta hak asasi manusia; 3) Wadah bertoleransi beragama serta berkeyakinan kepada Tuhan Yang Maha Esa sesama masyarakat; 4) Jadi bentuk cinta kepada Tuhan.

b. Kemanusiaan yang Adil dan Beradab

Dalam sila kedua, penulis secara implisit menciptakan sisi humanis dalam badan Pancasila. Bertepatan dengan itu, bersumber pada prinsip ini, penulis pula menciptakan sebagian nilai lain, semacam; 1) cinta sesama masyarakat; 2) persamaan derajat; 3) keadilan serta peradaban di antara manusia merupakan teman Tuhan.

c. Persatuan Indonesia

Pada sila ketiga memiliki arti nilai- nilai kebangsaan serta persatuan di antara tiap rakyat Indonesia. Secara universal sebagian 
nilai yang tercantum dalam kode etik tersebut antara lain: 1) persatuan serta kesatuan segala rakyat Indonesia; 2) kecintaan pada bangsa serta tanah air Indonesia; 3) bentuk Bhineka Tunggal Ika

d. Kerakyatan yang adil dan beradab dalam Permusyawaratan/ Perwakilan

Dalam sila keempat ini, ada sebagian nilai unik yang berkaitan dengan kepemimpinan, kebijaksanaan, pemikiran, serta representasi. Secara universal, bagi uraian Suko Wiyono, terdapat sebagian nilai dalam sila keempat ini. Nilai- nilai tersebut antara lain; 1) Demokrasi serta Demokrasi, 2) Hikmah serta Kearifan, serta 3) Perundingan buat menggapai mufakat.

e. Keadilan Sosial Bagi Seluruh Rakyat Indonesia

Pada sila terakhir ini cenderung menekankan nilai keadilan nasional. Tidak hanya itu, penulis juga menciptakan nilainilai lain yang terpaut dengan sila kelima dari Suko Wiyono. Nilai- nilai kasus tersebut merupakan: 1) keadilan sosial, 2) kesejahteraan internal serta eksternal warga, 3) kekeluargaan serta gotong royong, 4) etika profesi bangsa.

Lewat ulasan prinsip- prinsip di atas hingga bisa dikatakan kalau Pancasila merupakan landasan ideologis (diucap pula pandangan hidup) yang sangat sesuai untuk segala rakyat Indonesia. Di sisi lain, Pancasila pula dapat melahirkan banyak kalangan, banyak parpol untuk seluruh orang yang jadi bangsa Indonesia. Pelaksanaan Pancasila pula tidak dibatasi oleh waktu. Sepanjang ini telah teruji. Sepanjang ini Pancasila masih menempati tempat istimewa di hati warga Indonesia. Sementara itu dalam praktiknya, nilai Pancasila semacam tersebut di atas berangsur- angsur lenyap bersamaan dengan pergantian era serta globalisasi.

\section{Tantangan Pancasila di Masa Global}

Secara totalitas, globalisasi tidak cuma pengaruhi orang. Tetapi tidak cuma itu. Dalam pertumbuhan globalisasi, globalisasi berakibat pada seluruh negeri di dunia, semacam halnya negeri tumbuh semacam Indonesia.
Dalam proses pertumbuhan globalisasi, penumpukan kebudayaan sangat kokoh. Para partisipan globalisasi, tercantum warga Indonesia, kerapkali memandang budaya asing masuk ke Indonesia tanpa memikirkan budayanya sendiri. Budaya yang dimasuki umumnya dikejar serta dimanfaatkan oleh kanak- kanak negeri ini. Dampaknya anakanak di negeri ini cenderung memakai budaya yang bukan berasal dari negaranya sendiri, serta budaya ini malah berdekatan dengan Pancasila di dasar pengaruh pandangan hidup nasional dalam pelaksanaannya.

Suasana yang ditafsirkan oleh penulis di atas ialah salah satu wujud kemerosotan identitas bangsa. Dalam keadaan dikala ini, penerus negeri belum betul- betul mengaplikasikan nilai- nilai pandangan hidup nasional semacam dijabarkan di atas. Anakanak di negara ini cenderung merendahkan pemahaman nasionalisme mereka demi peradaban eksternal yang dikira lebih menarik serta modern.

Tantangan terbanyak negeri untuk dunia yang mengglobal ini merupakan merosotnya nilai- nilai nasional. Perihal ini diakibatkan oleh tingginya budaya luar yang masuk. Pada disaat yang sama, dalam praktiknya, belum terdapat filter untuk memetakan budaya mana yang sesuai buat diserap serta mana yang tidak baik buat diserap. Oleh sebab itu dalam pelaksanaannya diharapkan Pancasila bisa jadi penyaring serta bisa menjauhkan anakanak negara ini dari pengaruh kurang baik globalisasi.

\section{Penyimpangan Nilai Pancasila di Masa Global}

Di era modern ini, terdapat sebagian penyimpangan nilai Pancasila. Walaupun sebagian orang masih memegang teguh nilainilai tersebut, tetapi tanpa disadari tiap orang sudah mempraktikkan penyimpangan tersebut secara merata. Perbedaannya antara lain:

a. Penyimpangan Sila Pertama

Walaupun tiap orang berhak buat melaksanakan serta/ ataupun tidak melaksanakan aktivitas tertentu, tetapi dalam pemikiran Pancasila beribadah merupakan 
kewajiban tiap orang yang beriman. Terdapat bermacam berbagai wujud dari perintah awal, antara lain: 1) melanggar ketentuan agama, 2) meninggalkan ibadah, 3) menyangka diri selaku Tuhan serta Rasul, 4) meninggalkan agama, serta sebagainya.

Dalam Sila awal secara jelas dikatakan kalau, "Ketuhanan yang Maha Esa", yang maksudnya tiap orang berhak serta berkewajiban buat menyangka agama selaku keyakinan. Tidak cuma itu, mulai dari sila awal ini, Indonesia dapat dikatakan menampung kelompok agama.

b. Penyimpangan Sila Kedua

Pada sila kedua berfokus pada aspek manusia. Di era saat ini ini, warga Indonesia sudah melanggar hukum kedua. Warga Indonesia pada masa saat ini ini terbiasa tidak memanusiakan manusia. Perihal ini pasti saja berlawanan dengan prinsip kedua Pancasila.

Contoh instan pelanggaran sila kedua Pancasila di masa globalisasi merupakan; 1) pembunuhan, 2) penganiayaan, 3) perbudakan modern, 4) perampokan, 5) perampokan serta kejahatan yang lain. Contoh permasalahan di atas ialah pelanggaran terhadap perintah kedua Pancasila.

c. Penyimpangan Sila Ketiga

Penyimpangan hukum sila ketiga nampak dari memudarnya nilai- nilai persatuan bangsa. Tiap kelompok komunitas mempunyai nama kelompoknya sendiri. Prinsip individualisme serta apalagi rasisme saat ini jadi buta. Saat ini tidak lagi susah untuk warga buat mengutuk serta memperlakukan kelompok lawan yang lain selaku rival.

Bisa dilihat kalau terdapat contoh nyata dari pelanggaran terhadap perintah ketiga. 1) Jumlah konflik antar masyarakat, 2) Meningkatnya jumlah penganiayaan terhadap minoritas, 3) Meningkatnya isu SARA, dll. Keadaan tersebut melambangkan kemerosotan persatuan bangsa serta pelanggaran nyata terhadap Pancasila.

d. Penyimpangan Sila Keempat

Pada sila keempat secara universal mangulas tentang wujud kepemimpinan serta organisasi yang terdapat di Indonesia. Selaku negeri yang majemuk, Pancasila merangkul seluruh kelompok lewat pelaksanaan wujud pemerintahan yang berorientasi pada rakyat, kebijakan serta musyawarah/ perwakilan. Tetapi pada realitasnya, pemerintah, tercantum organisasi serta kelompok, beroperasi dengan sistem kepentingan privat.

Terdapat banyak contoh suasana yang menampilkan penyusutan perintah keempat. Dalam banyak permasalahan, permasalahan korupsi, kolusi, serta nepotisme ialah wujud pelanggaran hukum keempat yang sesungguhnya. Kepentingan swasta sudah jadi arah penerapan pemerintah. Apalagi dengan sebagian pemimpin yang jujur serta adil, aplikasi kotor yang disebutkan di atas tampaknya sudah jadi rahasia universal di warga Indonesia.

e. Penyimpangan Sila Kelima

Pada sila kelima tentang keadilan untuk segala rakyat Indonesia. Tetapi tampaknya, Indonesia masih hadapi ketidakadilan di banyak bidang. Banyak dampak pembelajaran serta kesehatan pada aplikasi sosial mencerminkan ketidakadilan. Dalam aplikasi pembelajaran, masih banyak anak miskin yang tidak bersekolah, serta anggaran pembelajaran sudah menggapai tingkatan paling tinggi. Dari segi kebersihan, masih banyak masyarakat miskin yang terpaksa wajib membeli obat dari warung makan sebab tidak sanggup berobat ke rumah sakit.

Indonesia memanglah mempunyai sistem kartu Indonesia yang sehat. Tetapi tampaknya, masih terdapat sebagian permasalahan rumah sakit serta institusi kesehatan yang menolak penderita miskin sebab pemerintah belum membayar anggaran kesehatan" Kartu Indonesia Sehat".

\section{Upaya Warga Global dalam Membudayakan Nilai Pancasila}

Globalisasi sendiri ialah tantangan yang dialami Indonesia. Selaku negeri tumbuh, Indonesia wajib mengalami perkara moral serta nasionalisme yang terus menjadi punah akibat globalisasi. Selaku solusinya, Indonesia bisa menanamkan pandangan hidup Pancasila pada generasi penerus.

Pancasila bisa dimengerti di seluruh bidang pembelajaran. Bagaimanapun, uraian 
yang sangat efisien bisa diberikan dalam pembelajaran resmi semacam sekolah. Dengan membagikan uraian tersebut mahasiswa ataupun warga bisa mempunyai uraian yang baik tentang nasionalisme. Paling tidak dalam perihal ini, nilai- nilai global yang berlawanan dengan aspek kebangsaan hendak terpinggirkan.

Dalam perihal penyelenggaraan pembelajaran itu sendiri, Pancasila menemukan atensi jangka panjang. Pembelajaran pancasila sudah dilaksanakan dari masa orde baru sampai sebagian tahun setelah itu. Tetapi sehabis masa reformasi, pembelajaran Pancasra seakan- akan telah sirna dari dunia. Suasana ini berakibat kurang baik pada kanak- kanak negeri. Dikala itu, perluasan budaya asing merambah keseriusan yang besar. Walhasil, warga Indonesia berbondong- bondong mempraktikkan budaya baru yang dikira lebih menarik, walaupun pada dasarnya tidak berguna untuk mereka.

Pengabaian pembelajaran Pancasila di masa kemudian menimbulkan orang Indonesia membebaskan nilai- nilai kebangsaan. Oleh sebab itu, buat melenyapkan kasus tersebut serta tingkatkan nilai nasionalisme semacam di masa kemudian, Indonesia wajib melakukan pembelajaran Pancasila di seluruh susunan warga. Bagi riset Hidayatillah (2014), pembelajaran serta Pancasila ialah 2 perihal yang silih berkaitan. Dalam pembukaan UUD 1945, terdapat yang berkata kalau salah satu cita- cita negeri merupakan mencerdaskan negeri. Prinsip kedua pula mengatakan ikatan antara pembelajaran serta Pancasila. Terdapat yang semacam ini dalam sila," Kemanusiaan yang adil serta beradab" maksudnya bangsa Indonesia wajib adil serta beradab. Pada dikala yang sama, buat menggapai peradaban serta keadilan, manusia memerlukan pembelajaran yang setara serta bermutu.

Secara universal penanaman nilai- nilai Pancasila tidak terbatas pada pembelajaran resmi. Dalam sebagian perihal, Kamu pula bisa menggunakan waktu libur nasional buat meningkatkan nilai dasar Pancasila. Dengan melakukan jadwal spesial buat menggunakan momen- momen hari berarti nasional tersebut, dalam proses penerapannya dicoba aktivitas kenaikan nilai nasionalisme. Tetapi pelaksanaan nilai- nilai Pancasila dengan metode ini tidak dapat dicoba sendiri, melainkan memerlukan pengajar semacam guru serta dosen. Lewat tutorial dosen serta ataupun guru, mahasiswa, mahasiswa ataupun warga universal dapat memperoleh uraian tentang tiap nilai yang terjalin di hari libur nasional.

Guru, dosen apalagi warga dapat bisa menanamkan nilai- nilai nasionalisme serta pancasila. Metode terbaik merupakan dengan membagikan pengalaman, deskripsi ilmiah, analogi serta pelajaran yang tercantum di tiap fenomena etnis. Metode meningkatkan jiwa nasionalisme dapat ditempuh dengan mengajak warga (serta dirinya sendiri) buat membeli serta komsumsi produk dalam negara. Dengan metode ini warga hendak diajari gimana menghormati sesama orang Indonesia. Di sisi lain, bersamaan dengan pembelian produk dalam negara warga, secara tidak langsung warga menunjang pertumbuhan ekonomi kerakyatan.

Memupuk jiwa nasionalisme tidak menyudahi hingga di atas. Terdapat banyak metode yang dapat diambil komunitas. Tiap tata cara yang ada tergantung pada keahlian tiap- tiap komunitas. Metode yang disebutkan di atas merupakan semacam ini; 1) Memberitahukan data tentang berartinya nasionalisme kepada warga; 2) Meningkatkan semangat gotong royong; 3) Membentuk perkumpulan serta organisasi yang berorientasi pada kerakyatan; 4) Memeringati tiap-tiap dalam ulasan hari libur nasional Hari libur nasional; 5) Diskusikan dengan kalangan nasionalis tentang subjek nasionalisme artistik.

Di masa globalisasi ini, persoalannya bukan seberapa baik implementasinya, tetapi gimana menarik anak- anak bangsa pada aktivitas serta olah raga yang bercirikan nasionalis. Lewat upaya- upaya tersebut di atas, bila terus dicoba hingga warga mempunyai sisi nasionalis yang baik. Dengan metode demikian, pada sesi berikutnya warga bisa dengan gampang serta terus menerus mempraktikkan nilai- nilai yang tertanam dalam Pancasila. 


\section{KESIMPULAN}

Untuk membuat bangsa yang besar, bangsa Indonesia harus menanamkan sikap nasionalisme semenjak dini, sejak kecil, maupun sejak masa sekolah dasar. Untuk menanggulangi kasus dan untuk menaikkan rasa nasionalisme bangsa Indonesia ialah dengan dilatih tentang sikap- perilaku yang baik sesuai dengan nilai- nilai dari Pancasila, tidak memusatkan hal- perihal yang melanggar nilai- nilai Pancasila, menanamkan rasa cinta tanah air sejak dini, melestarikan budaya Bangsa Indonesia, dan bagikan uraian kepada segala bangsa Indonesia kalau berartinya nasionalisme terhadap masa depan bangsa Indonesia.

Dunia yang damai serta Martabat yang diprakarsai oleh pendiri negeri Indonesia memerlukan fakta untuk menunjang implementasi Pancasila dalam pemerintahan negara. Pancasila hendak tetap jadi inspirasi untuk segala aspek kehidupan berbangsa serta bernegara, tercantum dalam formulasi bermacam peraturan perundangundangan. Oleh sebab itu, bangsa Indonesia mempunyai landasan moralitas serta nasionalisme yang jelas serta berpandangan jauh ke depan. Titik dini serta tujuan harapan sangat berarti untuk pembangunan berkepanjangan serta kejayaan negeri.

Dengan landasan yang kuat serta watak dan semangat karakter yang kokoh, hingga tidak hendak gampang terbawa- bawa oleh trend globalisasi, pula tidak hendak terbawa- bawa oleh sistem hukum eksternal yang mempunyai karakteristik serta kepentingan karakter sendiri- sendiri. Oleh sebab itu penyelenggara negara berkewajiban untuk melindungi karakter yang luhur serta cita- cita moral yang luhur rakyat yang ditegaskan dalam tafsiran umum UUD 1945. Teladan pemimpin hendak pengaruhi sosial budaya serta pada kesimpulannya akan tingkatkan kepribadian bangsa.

Arus globalisasi merupakan tren yang tidak dapat dihentikan oleh negara mana juga, termasuk Indonesia. Kondisi ini pastinya bakal berakibat pada nilai- nilai aristokrat yang diturunkan oleh tokoh- tokoh nasional. Perbandingan nilai yang begitu besar sehingga jati diri bangsa berangsur- angsur sirna, bahkan berangsur- angsur lenyap.

Sementara itu, Pancasila dapat menampung seluruh benda itu. Dalam Pancasila banyak terselip nilai- nilai luhur yang mencerminkan budaya bangsa. Warga Indonesia sesungguhnya mempunyai yang disebut ideologi dalam Pancasila. Untuk menjauhi seluruh akibat negatif yang ditimbulkan oleh globalisasi, bangsa Indonesia hanya butuh menguasai serta mengamalkan Pancasila sedekat mungkin.

Tetapi, di tengah gelombang globalisasi yang terus menjadi bertambah, warga Indonesia saat ini sudah melupakan nilai- nilai Pancasila. Tren globalisasi terus menjadi bertambah, serta warga tergiur dengan budaya asing yang dikira lebih menarik. Pelan tetapi pasti, warga melupakan nilai- nilai kebangsaan yang tercantum dalam Pancasila.

Salah satunya metode untuk mengembalikan nilai- nilai Pancasila merupakan dengan mengenalkannya kembali ke masyarakat. Triknya dengan menanamkan nilai- nilai kebangsaan sambil menggelar hari libur nasional di tiap pertemuan. Tidak hanya itu dapat pula lewat jalan pembelajaran. Dengan metode ini, pendidik bisa menanamkan banyak pemikiran kebangsaan di golongan siswa. Tidak hanya jalan pembelajaran, itu pula dapat dicapai lewat pertunjukan serta seni. Seniman dapat melaksanakan pameran dengan nilai- nilai nasionalis. Dengan begitu, masyarakat sanggup menyerap sisi nasionalisme.

Terakhir, butuh dilakukan upaya untuk menanamkan nilai- nilai luhur Pancasila. Tata cara di atas merupakan contoh dari apa yang dapat dicoba. Tidak hanya contoh di atas, orang pula bisa mempraktikkan tata cara lain yang lebih dipersonalisasi. Lewat cara- cara tersebut diharapkan warga bisa lebih menguasai, menyerap serta mengapresiasi nilai- nilai Pancasila serta mengaplikasikannya selaku identitas bangsa dalam kehidupannya 


\section{DAFTAR RUJUKAN}

Alius, S. (2016). Resonansi Kebangsaan: Pancasila dalam Pusaran Globalisasi. Jurnal Keamanan Nasional, 2(1), 141-158.

Asmaroini, A. P. (2016). Implementasi NilaiNilai Pancasila Bagi Siswa Di Era Globalisasi. Citizenship Jurnal Pancasila dan Kewarganegaraan, 4(2), 440-450.

Budimansyah, D. (2010). Tantangan globalisasi terhadap pembinaan wawasan kebangsaan dan cinta tanah air di sekolah. Jurnal Penelitian Pendidikan, 11(1), 8-16.

Budiwibowo, S. (2016). Revitalisasi Pancasila Dan Bela Negara Dalam Menghadapi Tantangan Global Melalui Pembelajaran Berbasis Multikultural. Citizenship Jurnal Pancasila dan Kewarganegaraan, 4(2), 565-585.

Danniarti, R. (2017). Implementasi NilaiNilai Pancasila Sebagai Pendukung Tumbuh Kembang Wawasan Kebangsaan pada Mata Pelajaran PPKn di SMP Negeri 7 Palembang. JMKSP (Jurnal Manajemen, Kepemimpinan, dan Supervisi Pendidikan), 2(2), 187-202.

Harefa, A. (2011). Implementasi Pancasila sebagai dasar filsafat dalam kehidupan berbangsa dan bernegara. Didaktik: Jurnal Ilmiah Pendidikan, Humaniora, Sains, dan Pembelajarannya, 5(2), 437-451.

IRHADI, Y. (2020). PERAN GURU PENDIDIKAN AGAMA ISLAM DALAM MENUMBUHKAN WAWASAN KEBANGSAAN DI SMP NEGERI 23 BANDAR LAMPUNG (Doctoral dissertation, UIN Raden Intan Lampung).

Irhandayaningsih, A. (2012). Peranan Pancasila dalam menumbuhkan kesadaran nasionalisme generasi muda di era global. Humanika, 16(9).

Lestari, E. Y. (2019). Menumbuhkan kesadaran nasionalisme generasi muda di era globalisasi melalui penerapan nilai-nilai Pancasila. ADIL Indonesia Journal, 1(1).

Mahendra, P. R. A. (2018). Pembelajaran PPKn Dalam Resonansi Kebangsaan dan Globalisasi. Jurnal Ilmiah Ilmu Sosial, 4(2), 120-126.

Martodirjo, H. S. (2008). Implementasi Pancasila dalam Menumbuhkembangkan Wawasan Kebangsaan. Jurnal Ketahanan Nasional, 13(1), 1-14.

Putri, A. L., Charista, F. D. F., Lestari, S., \& Trisiana, A. (2020). Implementasi Pancasila Dalam Pembangunan Dibidang Pendidikan. TERAMPIL: Jurnal Pendidikan dan Pembelajaran Dasar, 7(1), 13-22.

Rahman, A. (2018). Nilai Pancasila Kondisi Dan Implementasinya Dalam Masyarakat Global. Syntax Literate; Jurnal Ilmiah Indonesia, 3(1), 34-48.

Suryatni, L. (2016). WAWASAN KEBANGSAAN SEBAGAI PENCERMINAN NILAI-NILAI PANCASILA DALAM KEHIDUPAN BERBANGSA DAN BERNEGARA. Ejournal Widya Non-Eksakta, 1(1), 4655.

Thane, S. (2012). Empat pilar kehidupan berbangsa dan bernegara.

Widayanti, W. P., Armawi, A., \& Andayani, B. (2018). Wawasan kebangsaan siswa sekolah menengah atas dan implikasinya terhadap ketahanan pribadi siswa (Studi pada siswa sekolah menengah atas (SMA) umum berasrama berwawasan nusantara, SMA umum di lingkungan militer dan SMA umum di luar lingkungan militer di kabupaten Magelang, provinsi Jawa Tengah). Jurnal Ketahanan Nasional, 24(1), 1-26. 